\title{
Purification, characterization, gene cloning and expression of GH-10 xylanase (Penicillium citrinum isolate HZN13)
}

\author{
Zabin K. Bagewadi ${ }^{1} \cdot$ Sikandar I. Mulla $^{1} \cdot$ Harichandra Z. Ninnekar $^{1}$ (D)
}

Received: 27 May 2016/Accepted: 2 August 2016/Published online: 13 August 2016

(c) The Author(s) 2016. This article is published with open access at Springerlink.com

\begin{abstract}
An extracellular thermostable xylanase (Xyl-IIb) produced by Penicillium citrinum isolate HZN13 was purified to homogeneity using DEAE-Sepharose, Sephadex G-100 and Bio-Gel P-60 chromatography with specific activity of $6272.7 \mathrm{U} / \mathrm{mg}$ and 19.6-fold purification. The purification revealed the occurrence of multiple forms of xylanases (Xyl-I, Xyl-IIa, Xyl-IIb and Xyl-III). The molecular mass of highly purified Xyl-IIb was $\sim 31 \mathrm{kDa}$ with SDS-PAGE. The enzyme was cellulase-free, thermostable $\left(55-75^{\circ} \mathrm{C}\right)$ and acidophilic (3.5-5.0). It was activated by $\mathrm{Ca}^{2+}, \mathrm{Ba}^{2+}$, DTT and $\beta$-mercaptoethanol, whereas inhibited by $\mathrm{Hg}^{2+}, \mathrm{Pb}^{2+}, \mathrm{Ni}^{2+}$ and $p$-CMB. Purified Xyl-IIb exhibited highest specificity toward birchwood and oat spelts xylan. Kinetics of Xyl-IIb revealed a $K_{\mathrm{m}}$ of $10 \mathrm{mg} / \mathrm{ml}$ and $16.7 \mathrm{mg} / \mathrm{ml}$ and $V_{\max }$ of $9523 \mathrm{~g}$ and $15,873 \mathrm{U} / \mathrm{mg}$ with birchwood and oat spelts xylan, respectively, indicating high affinity toward birchwood xylan. The xylanase (Xyl-IIb) belongs to glycosyl hydrolase $(\mathrm{GH})$ family 10 based on conserved regions. Xylanase-encoding gene $(x y n B)$ consists of 1501 bp with an open reading frame of $264 \mathrm{bp}$ which was predicted to encode a protein having 87 amino acids and shared homology with endo-1,4-beta-xylanase $(x y n B)$ gene from Penicillium citrinum. Cloned $x y n B$ gene was expressed in E. coli BL21 (DE3) with xylanase activity $(80 \mathrm{U} / \mathrm{mg})$ and confirmed to be GH-10 Xyl-IIa based on molecular mass
\end{abstract}

Electronic supplementary material The online version of this article (doi:10.1007/s13205-016-0489-4) contains supplementary material, which is available to authorized users.

Harichandra Z. Ninnekar

hzninnekar@yahoo.com

1 Department of Biochemistry, Karnatak University, Dharwad, Karnataka 580 003, India
( $\sim 40 \mathrm{kDa})$. These properties of xylanase make it promising for their applications in biofuel industries.

Keywords Xylanase - Penicillium citrinum - Purification · Characterization $\cdot$ Cloning and expression

\section{Introduction}

Xylan, the structural polysaccharide, is a heteroglycan composed of a backbone of $\beta$-(1,4)-linked D-xylopyranosyl residues. Different substituents like L-arabinofuranose, Dglucuronic acid, and 4-o-methyl-D-glucuronic acid are attached at $2^{\prime}$ and $3^{\prime}$ positions (Wakiyama et al. 2008). The complete hydrolysis of xylan requires the synergistic action of different xylanolytic enzymes (xylanase, $\beta$-xylosidase, $\alpha$-L-arabinofuranosidase, $\alpha$-D-glucuronidase and acetyl xylan esterase) (Beg et al. 2001). Among them, xylanases (EC 3.2.1.8) deserve special attention as they degrade major hemicellulosic polysaccharides by catalyzing the hydrolysis of xylopyranosyl linkages of $\beta-1,4-x y l a n$ (Zhang et al. 2011). Xylanases are used in biobleaching of pulp in paper industry, bioconversion of lignocellulosic waste into fermentative products, improvement of animal feed quality and clarification of fruit juices and wines (Fang et al. 2010; Juturu and Wu 2012; Maity et al. 2012). Xylanases are produced from a variety of agricultural wastes. Sweet sorghum bagasse is cheap, widely distributed, available in plenty and serves as a better feedstock for xylanase production as it is non-food based agricultural residue having high carbohydrate content. Sweet sorghum is unique among the other crops as feedstock for renewable energy due to high photosynthetic activity, thereby generating high biomass yields and also survives water deficit conditions, abiotic stresses, heat and dry environments, 
water logging, salinity, alkalinity and other constraints (Teshome and Charles 2014). Highly active, thermostable xylanases are useful for industrial applications. Xylanases are widely distributed in bacteria, fungi and actinomycetes. However, fungal sources are most desirable for enzyme production due to their higher stability even under harsh environmental conditions (Moretti et al. 2012). Several filamentous fungi, which exhibit high xylan-degrading capabilities and thus producing multiple xylanases, have been studied (Liao et al. 2012). Aspergillus sp. and Trichoderma sp. are the most dominant among the high xylanase producers and commonly employed at an industrial level. Other strains like Penicillium oxalicum GZ-2 have been reported (Liao et al. 2014). However, there are few reports on the occurrence of multiple xylanases from Penicillium species (Liao et al. 2015). Current research on exploring new xylanases still exists (Miao et al. 2015). Based on the sequence similarities of amino acid, xylanases are classified into glycosyl hydrolase $(\mathrm{GH})$ families 10 (GH10) and 11 (GH11) (Guillen et al. 2010), but other GH families like 5, 8 and 43 are also found (http://www.cazy. org). GH 10 contains xylanases of high molecular mass $(>30 \mathrm{kDa})$ with a $(\beta / \alpha)_{8}$ barrel structure and acidic $p I$ values. GH11 are the low-molecular-weight endoxylanases (Henrissat and Bairoch 1996) which are divided into alkaline $p I$ and acidic $p I$ xylanases. Moreover, these enzymes within each family do not necessarily share similar enzymatic properties (Jørgensen et al. 2003). Many xylanases from bacteria and fungi have been cloned and characterized. Several xylanases genes from Penicillium sp. have been cloned and expressed, such as Penicillium citrium XynA, Penicillium funiculosum XYNC, Penicillium sp. strain 40 XynA, Penicillium purpurogenum XynB, and Penicillium janthinellum (Liu et al. 2010). There are very few reports on $x y n B$ gene from Penicillium citrinum (Ahmed et al. 2009). In this paper, we report the occurrence of multiple xylanases as well as purification, properties, gene cloning and sequencing and expression of GH10 xylanase from Penicillium citrinum isolate HZN13.

\section{Materials and methods}

\section{Chemicals, strains and vectors}

Chemicals, substrates and column matrix used were purchased from Sigma-Aldrich (USA), Merck (USA) and BioRad (France). Sweet sorghum stalks were provided by University of Agricultural Sciences, Dharwad. E. coli DH5 $\alpha$ and $E$. coli BL21 (DE3) were used for gene cloning, sequencing and expression studies, respectively. pGEM-T and pGEX-4T-1 were used as cloning and expression vectors, respectively.

\section{Xylanase production conditions}

A fungal strain previously isolated in our laboratory from forest soil and identified as Penicillium citrinum isolate HZN13 was used in the present study. Xylanase production by Penicillium citrinum isolate HZN13 was carried out by solid state fermentation (SSF) using alkali-pretreated sweet sorghum bagasse in 250-ml Erlenmeyer flasks in modified Mandels-Weber medium containing $(\mathrm{g} / \mathrm{l})$ urea 0.3; ammonium sulfate $1.4 ; \mathrm{KH}_{2} \mathrm{PO}_{4} 0.3 ; \mathrm{CaCl}_{2} 0.3 ; \mathrm{MgSO}_{4}$ $7 \mathrm{H}_{2} \mathrm{O} \quad 0.3$; yeast extract 1.0 ; lactose 10 ; and $(\mathrm{mg} / \mathrm{l})$ $\mathrm{FeSO}_{4} \cdot 7 \mathrm{H}_{2} \mathrm{O} \quad 5.0 ; \mathrm{MnSO}_{4} \cdot 7 \mathrm{H}_{2} \mathrm{O} \quad 1.6 ; \mathrm{ZnSO}_{4} \cdot 7 \mathrm{H}_{2} \mathrm{O}$ 1.4; $\mathrm{CoCl}_{2}$ 2; Tween-80 $0.1 \%$ (pH 4) (Bagewadi et al. 2016). The clear supernatant obtained was used as a source of crude enzyme for further purification.

\section{Enzyme assay and protein determination}

Xylanase activity was determined using the modified method of Bailey et al. (1992) with $1 \%$ (w/v) birchwood xylan substrate. Cellulase activity was estimated using $1 \%$ $(\mathrm{w} / \mathrm{v})$ carboxymethyl cellulose (CMC) in sodium acetate buffer (pH 5) at $40{ }^{\circ} \mathrm{C}$ for $30 \mathrm{~min}$ using modified method (Eveleigh et al. 2009). The reducing sugars released from the above reactions were determined according to Miller (1959) by dinitrosalicylic acid (DNS) method. One unit (U) of enzyme activity was defined as the amount of enzyme that released $1 \mu \mathrm{mol}$ of the reducing sugars (glucose or xylose equivalent) per minute under standard assay conditions. Specific activity was expressed as units per milligram of protein. The concentrations of soluble proteins were estimated by BCA protein assay kit (Mulla et al. 2016). All assays were performed in triplicate, and the results are presented as mean \pm standard deviation.

\section{Enzyme purification}

Xylanase produced by Penicillium citrinum isolate HZN13 was purified by methods described previously (Bagewadi et al. 2016). Briefly, all purification steps were carried out at $4{ }^{\circ} \mathrm{C}$ unless otherwise specified. The crude enzyme was fractionated by $\left(\mathrm{NH}_{4}\right)_{2} \mathrm{SO}_{4}(80 \%$ saturation) and dialyzed (50 mM sodium citrate buffer, $\mathrm{pH} 4.0$ ). The enzyme solution was concentrated by ultrafiltration system (Amicon, USA) with a $10-\mathrm{kDa}$ cut-off membrane and lyophilized. The lyophilized enzyme was purified by DEAESepharose and Sephadex G-100 columns with $50 \mathrm{mM}$ sodium citrate buffer ( $\mathrm{pH} 4.0$ ) as a mobile phase. Further purification was carried out with Bio-Gel P-60 column $(3.4 \times 110 \mathrm{~cm})$ pre-equilibrated and eluted with $50 \mathrm{mM}$ sodium citrate buffer $(\mathrm{pH} 4.0)$ at a flow rate of $0.5 \mathrm{ml} / \mathrm{min}$. Fractions containing xylanase activity were pooled, concentrated and used for further characterization. 


\section{SDS-PAGE, zymogram analysis and amino acid sequencing}

The purified enzyme was subjected to sodium dedocyl sulfate-polyacrylamide gel electrophoresis (SDS-PAGE) according to the method described previously (Laemmli 1970). Protein bands on the gel were visualized by staining with Coomassie Brilliant Blue R-250. For zymogram analysis, a native PAGE electrophoresis was carried out with polyacrylamide gel $(10 \%)$ at $4{ }^{\circ} \mathrm{C}$ using TBE buffer ( $89 \mathrm{mM}$ Tris, $2 \mathrm{mM}$ EDTA, and $89 \mathrm{mM}$ boric acid). After electrophoresis, the gel was soaked in $50 \mathrm{mM}$ sodium citrate buffer $(\mathrm{pH} 4)$ containing $1 \%$ birchwood xylan and incubated for $30 \mathrm{~min}$ at $45{ }^{\circ} \mathrm{C}$ to detect xylanase activity and then stained with Congo red solution $(2 \mathrm{mg} / \mathrm{ml})$ for $15 \mathrm{~min}$ at room temperature. The gel was washed with $1 \mathrm{M}$ $\mathrm{NaCl}$ solution and transferred to $5 \%(\mathrm{v} / \mathrm{v})$ acetic acid solution. Clear areas in a dark red background indicated xylanase activity (Driss et al. 2012). For amino acid sequencing, the enzyme was digested with $\mathrm{V} 8$ protease (Wakiyama et al. 2008). The $\mathrm{N}$-terminal amino acid sequences of the protein and resulting peptide fragments were identified using protein sequencing system (Shimadzu, Japan).

\section{Biochemical characterization of purified xylanase}

The optimum $\mathrm{pH}$ of the purified xylanase was determined using different buffers described in previous study by Bagewadi et al. (2016). The enzyme stability in a $\mathrm{pH}$ range of 3.5-5.0 was determined after incubation for $3 \mathrm{~h}$. The optimum temperature for enzyme activity was determined between 20 and $85{ }^{\circ} \mathrm{C}$. The thermostability of xylanase was determined between 55 and $75{ }^{\circ} \mathrm{C}$ for $3 \mathrm{~h}$ at $\mathrm{pH}$ 4.0. The effect of various metal ions, thiol reagents, oxidizing agents, metal chelators and detergents at different concentrations of 2,5 and $10 \mathrm{mM}$ on the enzyme activity has been studied. The enzyme stability in the presence of various organic solvents was also evaluated. Substrate specificity of xylanase was determined using different substrates like $1 \%$ birchwood xylan, oat spelts xylan, CMC, microcystalline cellulose, chitin, cellobiose, starch, filter paper, pectin, PNP- $\alpha-$ galactopyranoside, PNP-glucopyranoside and PNP-cellobioside. The kinetics parameters $K_{\mathrm{m}}$ and $V_{\max }$ of purified Xyl-IIb were determined with birchwood and oat spelts xylan substrate with a concentration range of $2-20 \mathrm{mg} / \mathrm{ml}$ by Lineweaver-Burk double reciprocal plot.

\section{Cloning of xylanase gene (xynB) from Penicillium citrinum isolate HZN13}

The xylanase gene from Penicillium citrinum isolate HZN13 was amplified using the cDNA, reverse-transcribed from RNA (template). The following gene specific primers: forward primer: cggaattcatatggttcaaatcaag and reverse primer: cggaattcaaaggcctctagag (bold letters indicate Eco RI restriction sites) were designed based on the conserved sequences revealed by sequence alignment and comparative analysis of Penicillium citrinum xylanase homologous genes from the GenBank database. Reverse transcriptionpolymerase chain reaction (RT-PCR) (Eppendorf, Germany) was performed in $50 \mu \mathrm{l}$ reaction mixtures containing synthesized cDNA under the following conditions: 40 cycles of 1 min denaturation at $94{ }^{\circ} \mathrm{C}, 1$ min annealing at $48{ }^{\circ} \mathrm{C}$, and $1 \mathrm{~min}$ amplification at $72{ }^{\circ} \mathrm{C}$. The amplified products $(1.5 \mathrm{~kb})$ were gel-purified, ligated into the pGEM$\mathrm{T}$ vector and transformed into $E$. coli DH5 $\alpha$. Screening for xylanase-positive clones was carried out on $1 \%$ birchwood xylan-LB agar plates by Congo red plate assay. The clones with clear zones on the plates harbored xylanase gene.

\section{Sequence analysis and expression of $\mathrm{xynB}$ gene}

Recombinant plasmids (pGEM-T- $x y n B$ ) were isolated from xylanase-positive clones, and $x y n B$ gene sequencing was carried out using the Big Dye Terminator cycle sequencing kit (V3.1, Applied Biosystems, USA) according to the manufacturer's protocol and analyzed in a DNA Analyzer (3730 DNA Analyzer, Applied Biosystems, USA). Two independent PCR products were sequenced in both directions to confirm the sequence. Sequence analysis was carried out using BLASTn program (http://www.ncbi.nlm.nih. gov/). Gene sequences were aligned using ClustalW (http:// www.ebi.ac.uk/Tools/msa/clustalo/) (Ewing et al. 1998). Phylogenetic relationships were established using $x y n B$ gene sequence of isolated fungal strain (Penicillium citrinum isolate HZN13) with other related gene sequences (Tamura et al. 2013) by the neighbor-joining (NJ) method using MEGA6 software. The number at nodes showed the bootstrap values obtained with 1000 resampling analyses. The nucleotide sequence of gene was analyzed using the National Center for Biotechnology Information (NCBI) Open Reading Frame (ORF) Finder tool. Multiple sequence alignment of the putative amino acid sequence of xylanase with other related xylanases was carried out using the Clustal $W$ software.

Furthermore, $x y n B$ gene-amplified product was subcloned into pGEX-4T-1 expression vector (designated as pGEX-4T-1-xynB) and was expressed in E. coli BL21 (DE3). The expression of xylanase was examined by detecting xylanase activity from the culture broth of the recombinant strain. To induce xylanase production, the E. coli BL21 (DE3) transformants were grown in an LBampicillin medium at $37{ }^{\circ} \mathrm{C}$. When absorbance at $600 \mathrm{~nm}$ reached 0.5 , isopropyl- $\beta$-D-thiogalactopyranoside (IPTG) was added at the final concentration of $1 \mathrm{mM}$, and the 
transformants were grown for an additional $4 \mathrm{~h}$ at $25^{\circ} \mathrm{C}$. Cells were harvested, resuspended in PBS solution $(10 \mathrm{mM}$ $\mathrm{NaH}_{2} \mathrm{PO}_{4}, 150 \mathrm{mM} \mathrm{NaCl}, \mathrm{pH} 7.2$ ), and lysed by sonication. The supernatant was used for xylanase assay, and expression of $x y n B$ Gene was checked by SDS-PAGE. The nucleotide sequence of $x y n B$ gene from Penicillium citrinum isolate HZN13 was deposited in the GenBank with the Accession No. KU298274.

\section{Results and discussion}

\section{Purification of xylanase}

The properties of xylanase from Penicillium citrinum isolate HZN13 were assessed by purification by $\left(\mathrm{NH}_{4}\right)_{2} \mathrm{SO}_{4}$ precipitation, ultrafiltration, DEAE-Sepharose, Sephadex G-100 and Biogel P-60 chromatography. During ultrafiltration, maximum xylanase activity was detected in the retentate and used for subsequent purification. Three major peaks (Xyl-I, Xyl-II and Xyl-III) exhibiting xylanase activities were obtained from the column chromatography using DEAE-Sepharose matrix. Xyl-I was not retained on the column and was eluted out first, whereas Xyl-II and Xyl-III were retained onto the column which were eluted out with an established $\mathrm{NaCl}$ gradient as shown in Fig. S1A (Supplementary information, SI). However, Xyl-II showed higher activity (49,600 U) which was further purified by Sephadex G-100. This purification step resulted in two peaks designated as Xyl-IIa and Xyl-IIb containing proteins with xylanase activity (Fig. S1B). Xyl-IIb fraction obtained from chromatography with Sephadex G-100 matrix was re-purified by column chromatography using Bio-Gel P-60 matrix where Xyl-IIb was eluted out as a single sharp homogenous peak, as revealed from the chromatogram, indicating high purity (Fig. S1C). The yield and fold purification of Xyl-IIb were $11.5 \%$ and 19.60, respectively, with specific activity of $6272.7 \mathrm{U} / \mathrm{mg}$ protein as shown in Table 1. The purification reveals the presence of multiple isoforms of xylanase.

\section{Molecular mass determination, zymogram and amino acid sequence analysis}

The highly purified Xyl-IIb showed a single protein band on SDS-PAGE (Lane 3) with molecular weight of $\sim 31 \mathrm{kDa}$, and Xyl-IIa purified by Sephadex G-100 showed a protein band of molecular mass of $\sim 40 \mathrm{kDa}$ (Lane 1) as shown in Fig. 1. The protein bands were examined for their ability to hydrolyze the xylan incorporated into the gel. Three distinct bands and a smear in the region of high molecular weight showing xylanase activity were detected in the gel with crude extract. The smear region disappeared as purification proceeded, indicating the separation of higher molecular weight proteins (xylanases) during chromatography. The zymogram analysis revealed the fact that multiple xylanases of GH-10 family with high molecular masses were produced by Penicillium citrinum isolate HZN13. As reported in the literature (Henrissat and Bairoch 1996), xylanases with high molecular mass (>30 kDa) belong to GH-10 family. The purified Xyl-IIb was cellulase-free with no measurable activities with $\mathrm{CMC}$ and only showed activity with birchwood and oat spelts xylans as the substrates. Xylanases with differing molecular mass from different organisms have been studied, such as 19 and $14 \mathrm{kDa}$ from Trichoderma inhamatum (Silva et al. 2015) and $25 \mathrm{kDa}$ from Penicillium ramulosum N1 (Lin et al. 2015). Multiple xylanase forms have also been studied in A. fumigates Z5 (Miao et al. 2015) and Penicillium oxalicum GZ-2 (Liao et al. 2015). Edman degradation method for $\mathrm{N}$-terminal sequencing was unsuccessful most likely due to blockage of N-terminal amino acid. Such blockage is well reported in $\mathrm{GH}-10$ xylanase family (Wakiyama et al. 2008). However, the N-terminal sequence of peptide fragment was determined: NSMKWDATER. Protein database search for the peptide sequence revealed close homology to GH-10 family of xylanases.

\section{Biochemical characterization of purified xylanases}

\section{Effect of $\mathrm{pH}$ and temperature}

Multiple xylanases revealed different properties. Xyl-I, Xyl-IIa, Xyl-IIb and Xyl-III showed optimum activity at pH 6, 9, 4 and 5, respectively (Fig. 2a). Highly purified $\mathrm{Xyl}-\mathrm{IIb}$ was remarkably active in the acidic $\mathrm{pH}$ range of 3.5-5.0. 80, 90, 82 and $76 \%$ of Xyl-IIb activities were retained at $\mathrm{pH} 3.5,4,4.5$ and 5, respectively, after $3 \mathrm{~h}$ indicating its stability at acidic pH (Fig. 2b). Xyl-I, XylIIa, Xyl-IIb and Xyl-III showed optimum activity at temperatures 50, 55, 65 and $60{ }^{\circ} \mathrm{C}$, respectively (Fig. 2c). XylIIb was found to be highly stable at $55-75^{\circ} \mathrm{C}$ (Fig. $2 \mathrm{~d}$ ). Enzymatic stability at their optimum conditions is needed for catalytic efficiency. The results suggest the acidophilic nature and thermostability property of Xyl-IIb from Penicillium citrinum isolate HZN13 which can be exploited for industrial applications. Xylanase from Penicillium occitanis has been reported to be active at $\mathrm{pH} 3.0$ and $65^{\circ} \mathrm{C}$ (Driss et al. 2012) and that from Penicillium oxalicum GZ2 at $\mathrm{pH} 4.0$ and $60{ }^{\circ} \mathrm{C}$ (Liao et al. 2014). Wakiyama et al. (Wakiyama et al. 2008) reported xylanase from Penicillium citrinum to be optimal at $\mathrm{pH} 6.0$ and $50{ }^{\circ} \mathrm{C}$ and was stable at wide $\mathrm{pH}$ range and up to $40{ }^{\circ} \mathrm{C}$. 
Table 1 Purification summary of xylanase from Penicillium citrinum isolate HZN13

\begin{tabular}{|c|c|c|c|c|c|}
\hline Purification steps & Total protein $(\mathrm{mg})$ & Total activity $(\mathrm{U}) \times 10^{3}$ & Specific activity (U/mg) & Yield (\%) & Fold purification \\
\hline Crude extract & 750 & 240 & 320 & 100 & 1 \\
\hline Ammonium sulfate & 200 & 104 & 520 & 43.34 & 1.62 \\
\hline \multicolumn{6}{|l|}{ Fractionation $(80 \%)$} \\
\hline Ultrafiltration & 102 & 66 & 647 & 27.50 & 2.02 \\
\hline \multicolumn{6}{|l|}{ DEAE-Sepharose } \\
\hline Xyl-I & 18.90 & 47.70 & 2523.80 & 19.88 & 7.89 \\
\hline Xyl-II & 25.60 & 49.60 & 1937.50 & 20.67 & 6.05 \\
\hline Xyl-III & 4.40 & 17.20 & 3909.10 & 7.17 & 12.21 \\
\hline \multicolumn{6}{|l|}{ Sephadex G-100 } \\
\hline Xyl-IIa & 4.80 & 36 & 7500 & 15 & 23.43 \\
\hline Xyl-IIb & 10.50 & 46.90 & 4466.70 & 19.54 & 13.96 \\
\hline \multicolumn{6}{|l|}{ Bio-Gel P-60 } \\
\hline Xyl-IIb & 4.40 & 27.60 & 6272.70 & 11.50 & 19.60 \\
\hline
\end{tabular}

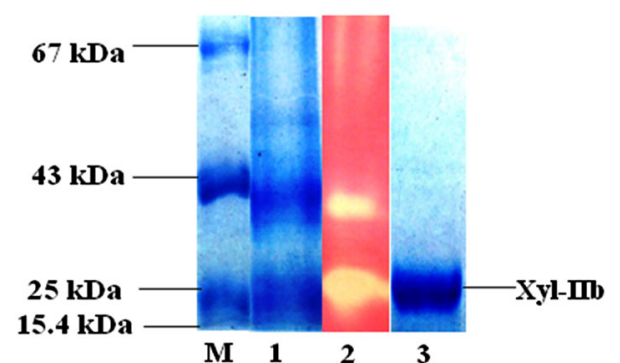

Fig. 1 SDS-PAGE and zymogram analysis. Lane $M$ standard molecular weight markers [RNase $(15.4 \mathrm{kDa})$, chymotrypsin $(25.0 \mathrm{kDa})$, ovalbumin $(43.0 \mathrm{kDa})$ and BSA $(67.0 \mathrm{kDa})]$. Lane 1 purified xylanase (Xyl-IIa and Xyl-IIb) on Sephadex G-100. Lane 2 activity of Xyl-IIa and Xyl-IIb coincident with protein bands. Lane 3 purified Xyl-IIb by Bio-Gel P-60 chromatography

Effect of metal ions, additives, surfactants, oxidizing agents and organic solvents

The effects of various metal ions on Xyl-IIb activity at 2, 5 and $10 \mathrm{mM}$ concentrations are shown in Table 2 . The metal ions such as $\mathrm{Ca}^{2+}$ and $\mathrm{Ba}^{2+}$ activated the enzyme Xyl-IIb, whereas $\mathrm{Hg}^{2+}, \mathrm{Pb}^{2+}, \mathrm{Ni}^{2+}, \mathrm{Cu}^{2+}$, and $\mathrm{Cd}^{2+}$ strongly inhibited $\mathrm{Xyl}-\mathrm{IIb}$ at different concentrations. Our results are similar to those reported for xylanase from Penicillium sclerotiorum (Knob and Carmona 2010) and Penicillium glabrum (Knob et al. 2013). Sulfhydryl compounds, such as DTT, $\beta$-mercaptoethanol and cysteine, activated Xyl-IIb, whereas sulphydryl inhibitors, such as iodoacetamide and $p$-CMB, inhibited the enzyme activity (Table 3). These results suggest the involvement of thiol groups in the enzyme activity. 1,10-phenanthroline, a $\mathrm{Fe}^{2+}$ specific chelator, drastically inhibited enzyme activity indicating the presence of $\mathrm{Fe}^{2+}$ at its active site. Inhibition of enzyme by oxidizing agents like $\mathrm{H}_{2} \mathrm{O}_{2}$ may be due to oxidation of $\mathrm{Fe}^{2+}$ to $\mathrm{Fe}^{3+}$ in the enzyme. Similar findings have been reported from Penicillium glabrum (Knob and Carmona 2010).

Xyl-IIb showed stability in the presence of detergents such as SDS. Xylanase from Trichoderma inhamatum (Silva et al. 2015) and Penicillium glabrum (Knob et al. 2013) have been reported to be inhibited by SDS. Surfactants like Tween-40 and Triton X-100 enhanced the enzyme activity at lower concentrations (Table 3 ). Surfactants have also been found to enhance the activity in $A$. fumigates Z5 (Miao et al. 2015).

Xyl-IIb showed a relative activity of greater than $85 \%$ in most of the organic solvents like glycerol, ethanol, methanol, acetone, propanol, petroleum ether, isopropanol, benzene, cyclohexane, hexane, butanol and toluene at $30 \%$ concentration except for formic acid which reduced the activity (Table 4). Solvent-tolerant property of enzymes is one of the important attributes of industrial enzymes. Solvent stability of xylanase from A. tubingensis FDHN1 has been reported (Adhyaru et al. 2015).

\section{Substrate specificity and kinetic studies}

The purified GH-10 Xyl-IIb showed highest substrate specificity toward birchwood and oat spelts xylan with 6273 and $4818 \mathrm{U} / \mathrm{mg}$ of specific activities, respectively. GH-10 xylanases are commonly found to be active on a wide range of substrates unlike $\mathrm{GH}-11$ family which shows specificity with few xylan substrates. No measurable activities were detected with other substrates indicating high substrate specificity and cellulase-free xylanase, which has potential application in pulp and paper industry. 

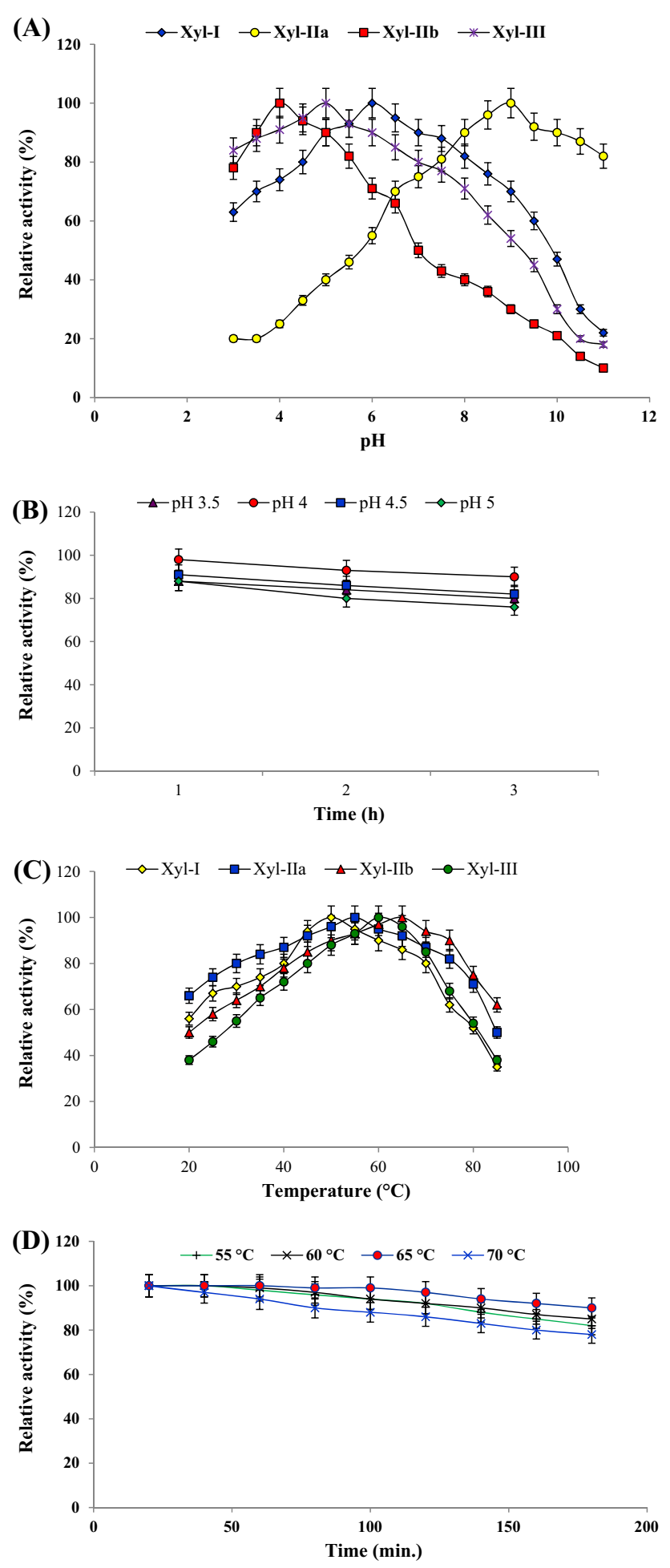

Fig. 2 Effect of pH on purified xylanase (Xyl-I, Xyl-IIa, Xyl-IIb and Xyl-III) (a), pH stability of Xyl-IIb (b), effect of temperature $\left({ }^{\circ} \mathrm{C}\right)$ on purified xylanase (Xyl-I, Xyl-IIa, Xyl-IIb and Xyl-III) (c), temperature stability of Xyl-IIb (d). Data values represent average of triplicates and error bars represent standard deviation
Kinetics of Xyl-IIb revealed a $K_{\mathrm{m}}$ of 10 and $16.7 \mathrm{mg} / \mathrm{ml}$ and $V_{\max }$ of 9523 and 15,873 $\mathrm{U} / \mathrm{mg}$ with birchwood and oat spelts xylan, respectively. Comparatively, Xyl-IIb showed high affinity toward birchwood xylan. Differences in solubility and structure of substrates influence the activity and kinetic parameters. A high $K_{\mathrm{m}}$ and $V_{\max }$ is observed with oat spelts xylan. Enzyme interaction with oat spelts xylan might have varied the characteristic features of active site. Similarly, higher catalytic specificity for soluble birchwood xylan was also reported from Trichoderma inhamatum (Silva et al. 2015). GH-10 family XYN11A from Penicillium oxalicum GZ-2 showed highest specific activity with beechwood xylan $(150.2 \mathrm{U} / \mathrm{mg})$ in comparison to birchwood xylan $(60.2 \mathrm{U} / \mathrm{mg})$ and oat spelts xylan $(72.6 \mathrm{U} / \mathrm{mg})$ and also represented high affinity toward beechwood xylan (Liao et al. 2014).

\section{Cloning, sequence analysis, and expression of xynB gene (Penicillium citrinum isolate HZN13)}

Using RT-PCR, a specific band of $1.5 \mathrm{~kb}$ was amplified from the total RNA of Penicillium citrinum isolate HZN13. The complete nucleotide sequence of $x y n B$ gene encoding any one of the xylanases (Xyl-I, Xyl-IIa, Xyl-IIb or XylIII) was determined. The nucleotide sequence was $1501 \mathrm{bp}$ in length. Sequence analysis confirmed that the RT-PCR product had high homology to the members of the xylanase gene family. The phylogenetic tree was constructed using Penicillium citrinum isolate HZN13 $x y n B$ gene with other related xylanase genes (organisms) as shown in Fig. 3. Open reading frame (ORF) was located between nucleotides 1279 and 1542 with a 264-bp length of DNA sequence and is predicted to encode a protein of 87 amino acids. Fig. S2 shows a comparison of the putative amino acid sequence from Penicillium citrinum isolate HZN13 with those available on the databases and revealed close identity with endo-1,4-beta-xylanase from Penicillium citrinum (GenBank Accession Number BAG12101) with up to 37 (amino acid) base mutations. Although recombinant xylanase was highly similar to endo-1,4-beta-xylanase from Penicillium citrinum, it harbored different characteristic properties. The 37 base mutations are of great value for further study. The recombinant xylanase from Penicillium citrinum isolate HZN13 belonged to glycosyl hydrolase $(\mathrm{GH})$ family 10 based on the highly conserved regions such as MVQIKAAAL, PRQASVSID, KFKAHGKKY, IKADF and NSMKWDATE. The deduced amino acid sequence of $x y n B$ gene was similar to the corresponding conserved region of fungal xylanases which have been classified into family GH-10. As previously 
Table 2 Effect of different metal ions on activity of purified Xyl-IIb

\begin{tabular}{llll}
\hline Metal ions & \multicolumn{2}{l}{ Relative activity $(\%)$} & $10 \mathrm{mM}$ \\
\cline { 2 - 4 } & $2 \mathrm{mM}$ & $5 \mathrm{mM}$ & 100 \\
\hline None & 100 & 100 & $98 \pm 0.6$ \\
$\mathrm{Co}^{2+}$ & $112 \pm 0.4$ & $110 \pm 0.5$ & $68 \pm 0.5$ \\
$\mathrm{Zn}^{2+}$ & $98 \pm 0.3$ & $90 \pm 0.6$ & $104 \pm 0.4$ \\
$\mathrm{Ca}^{2+}$ & $122 \pm 0.3$ & $118 \pm 0.7$ & $90 \pm 0.6$ \\
$\mathrm{Mg}^{2+}$ & $100 \pm 0.6$ & $97 \pm 0.4$ & $100 \pm 0.5$ \\
$\mathrm{Na}^{+}$ & $110 \pm 0.6$ & $107 \pm 0.4$ & $37 \pm 0.4$ \\
$\mathrm{Cu}^{2+}$ & $65 \pm 0.4$ & $50 \pm 0.3$ & - \\
$\mathrm{Hg}^{2+}$ & $30 \pm 0.5$ & $18 \pm 0.2$ & $70 \pm 0.5$ \\
$\mathrm{Fe}^{3+}$ & $90 \pm 0.4$ & $85 \pm 0.5$ & $20 \pm 0.6$ \\
$\mathrm{~Pb}^{2+}$ & $56 \pm 0.3$ & $45 \pm 0.7$ & $18 \pm 0.7$ \\
$\mathrm{Ni}^{2+}$ & $50 \pm 0.2$ & $40 \pm 0.6$ & $98 \pm 0.8$ \\
$\mathrm{Mn}^{2+}$ & $112 \pm 0.1$ & $106 \pm 0.4$ & - \\
$\mathrm{Cd}^{2+}$ & $35 \pm 0.3$ & $20 \pm 0.5$ & $110 \pm 0.6$ \\
$\mathrm{Ba}^{2+}$ & $128 \pm 0.2$ & $120 \pm 0.4$ & \\
\hline
\end{tabular}

Enzyme assay carried out with $1 \%(\mathrm{w} / \mathrm{v})$ birchwood xylan in citrate buffer $(\mathrm{pH} 4.0)$ at $55^{\circ} \mathrm{C}$ for 30 min in the absence of any metal ions was considered as $100 \%$. For the test samples, enzyme was pre-incubated with metal ions for $1 \mathrm{~h}$ prior to the assay

Experiments were carried out in triplicate and the results are presented as mean \pm standard deviation (SD)

\begin{tabular}{llll}
\hline Additives & \multicolumn{2}{l}{ Relative activity $(\%)$} & $10 \mathrm{mM}$ \\
\cline { 2 - 4 } & $2 \mathrm{mM}$ & $5 \mathrm{mM}$ & 100 \\
\hline None & 100 & 100 & $106 \pm 0.5$ \\
DTT & $122 \pm 0.5$ & $120 \pm 0.2$ & $98 \pm 0.6$ \\
$\beta$-Mercaptoethanol & $117 \pm 0.6$ & $111 \pm 0.5$ & $150 \pm 0.8$ \\
L-Cysteine & $166 \pm 0.6$ & $160 \pm 0.4$ & $30 \pm 0.8$ \\
PMSF & $65 \pm 0.4$ & $56 \pm 0.5$ & $20 \pm 0.9$ \\
NBS & $60 \pm 0.5$ & $50 \pm 0.3$ & $40 \pm 0.6$ \\
Iodoacetamide & $70 \pm 0.2$ & $68 \pm 0.1$ & $45 \pm 0.7$ \\
$p$-CMB & $68 \pm 0.5$ & $61 \pm 0.6$ & $52 \pm 0.4$ \\
$1,10-P h e n a n t h r o l i n e$ & $68 \pm 0.7$ & $28 \pm 0.7$ \\
$\mathrm{H}_{2} \mathrm{O}_{2}$ & $74 \pm 0.7$ & $47 \pm 0.5$ & $98 \pm 1.2$ \\
SDS & $65 \pm 0.6$ & $117 \pm 1.1$ & $107 \pm 0.7$ \\
Tween-40 & $125 \pm 0.9$ & $122 \pm 0.4$ & $90 \pm 0.4$ \\
Triton X-100 & $124 \pm 0.7$ & $93 \pm 0.4$ & \\
\hline
\end{tabular}

Enzyme assay carried out with $1 \%(\mathrm{w} / \mathrm{v})$ birchwood xylan in citrate buffer $(\mathrm{pH} 4.0)$ at $55{ }^{\circ} \mathrm{C}$ for $30 \mathrm{~min}$ in the absence of any additives was considered as $100 \%$. For the test samples, enzyme was pre-incubated with additives for $1 \mathrm{~h}$ prior to the assay

Experiments were carried out in triplicate and the results are presented as mean $\pm \mathrm{SD}$ reported, endo-1,4-beta-xylanase from Penicillium citrinum strain also belonged to $\mathrm{GH}-10$ family with these conserved regions (Wakiyama et al. 2008). The cloned gene, the coding sequence of xylanase, was subcloned into the expression vector pGEX-4T-1 and expressed in E. coli BL21 (DE3) for verification. Extracellular xylanase activity of $80 \mathrm{U} / \mathrm{mg}$ was detected from the culture broth of the recombinant strain. A $66-\mathrm{kDa}$ xylanase protein band from the cell-free extracts of E. coli BL21 (DE3) was shown on SDS-PAGE induced by IPTG, whereas in non-induced cell-free extracts of E. coli BL21 (DE3), no 66-kDa protein band was detected (Fig. 4). Xylanase was expressed as a fusion protein due to the presence of the glutathione S-transferase (GST)-tagged fusion peptide in expression vector pGEX-4T-1. Fusion protein with a molecular mass of $66 \mathrm{kDa}$ corresponds to the sum of xylanase (40 kDa) 
Table 4 Effect of different organic solvents on activity of purified Xyl-IIb

\begin{tabular}{lrrr}
\hline Organic solvent & \multicolumn{2}{c}{ Relative activity $(\%)$} & $30 \%$ \\
\cline { 2 - 4 } & \multicolumn{1}{c}{$10 \%$} & $20 \%$ & $110 \pm 0.9$ \\
\hline Glycerol & $125 \pm 1.2$ & $114 \pm 1.3$ & $90 \pm 0.8$ \\
Ethanol & $98 \pm 1.1$ & $94 \pm 1.2$ & $96 \pm 1.1$ \\
Methanol & $110 \pm 1.2$ & $100 \pm 1.4$ & $88 \pm 0.7$ \\
Acetone & $96 \pm 0.9$ & $92 \pm 0.6$ & $47 \pm 0.8$ \\
Formic acid & $72 \pm 0.9$ & $64 \pm 0.7$ & $89 \pm 0.9$ \\
Propanol & $96 \pm 0.8$ & $94 \pm 0.9$ & $90 \pm 0.6$ \\
Petroleum ether & $94 \pm 0.7$ & $91 \pm 1.1$ & $92 \pm 0.7$ \\
Isopropanol & $100 \pm 0.81$ & $96 \pm 0.7$ & $87 \pm 0.5$ \\
Benzene & $96 \pm 1.1$ & $91 \pm 0.8$ & $85 \pm 0.4$ \\
Cyclohexane & $95 \pm 1.2$ & $90 \pm 0.4$ & $76 \pm 0.7$ \\
Hexane & $92 \pm 0.9$ & $85 \pm 0.5$ & $93 \pm 0.8$ \\
Butanol & $112 \pm 0.7$ & $97 \pm 0.7$ & $92 \pm 0.4$ \\
Toluene & $115 \pm 0.5$ & $98 \pm 0.5$ & \\
\hline Enzyme & & & \\
\end{tabular}

Enzyme assay carried out with $1 \%(\mathrm{w} / \mathrm{v})$ birchwood xylan in citrate buffer $(\mathrm{pH} 4.0)$ at $55^{\circ} \mathrm{C}$ for $30 \mathrm{~min}$ in the absence of any organic solvent was considered as $100 \%$. For the test samples, enzyme was preincubated with organic solvent for $1 \mathrm{~h}$ prior to the assay

Experiments were carried out in triplicate and the results are presented as mean $\pm \mathrm{SD}$

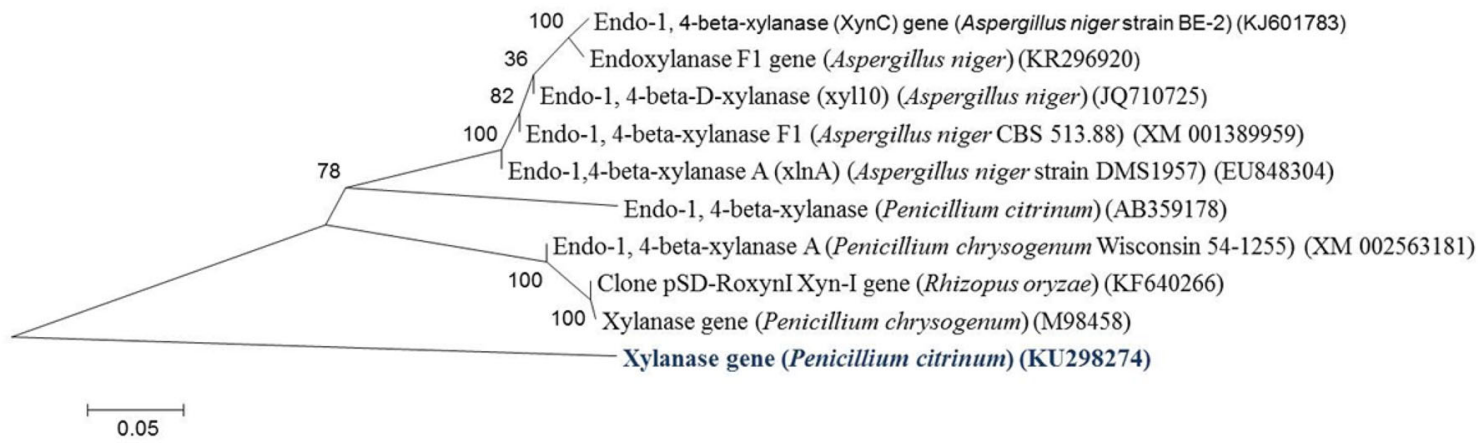

Fig. 3 Phylogenetic relationships established by the neighbor-joining (NJ) method using xylanase gene (xynB) sequence of Penicillium citrinum isolate HZN13 with other related sequences. The number at nodes shows the bootstrap values obtained with 1000 resampling analyses

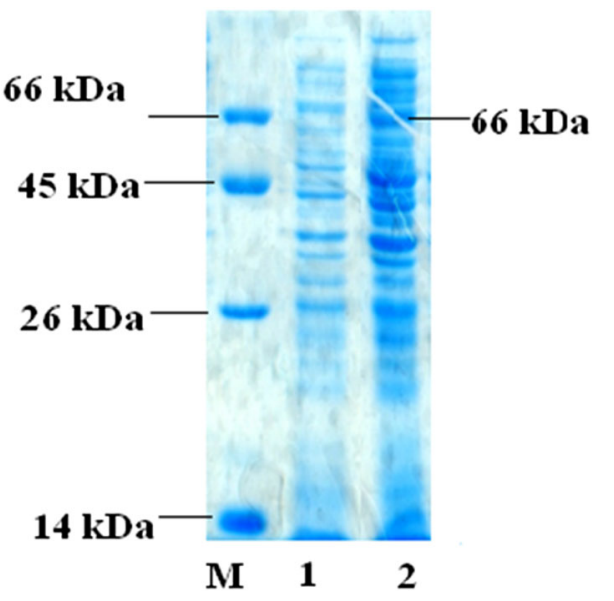

Fig. 4 SDS-PAGE of proteins expressed in BL21 (DE3). Lane $M$ four markers $(66,45,26,14 \mathrm{kDa})$. Lane 1 uninduced clone in BL21 (DE3) and Lane 2 induced clone in BL21 (DE3) and GST (26 kDa). From SDS-PAGE and zymogram analysis (Fig. 1), it can be concluded that $x y n B$ gene was successfully expressed as a Xyl-IIa protein in E. coli BL21 (DE3). These predictions are consistent with previously reported experimental data (Liao et al. 2015; Tanaka et al. 2005; Wakiyama et al. 2008).

\section{Conclusions}

In the present study, the Penicillium citrinum isolate HZN13 produced a highly active cellulase-free GH-10 xylanase (Xyl-IIb). The purified Xyl-IIb was found to be solvent-thermostable-acidophilic in nature and $x y n B$ gene encoded xylanase (Xyl-IIa) which belonged to GH-10 family. Cloning and expression of $x y n B$ gene was 
successful in E. coli BL21 (DE3). The purified enzyme finds huge potential in biofuel and other industries.

Acknowledgments First author acknowledges KLE Technological University, B.V. Bhoomaraddi College of Engineering and Technology, Hubballi and Research and Development Promotion Cell (RDPC) for providing research facility.

\section{Compliance with ethical standards}

Conflict of interest The authors declare that there is no conflict of interest regarding the publication of this article.

Open Access This article is distributed under the terms of the Creative Commons Attribution 4.0 International License (http:// creativecommons.org/licenses/by/4.0/), which permits unrestricted use, distribution, and reproduction in any medium, provided you give appropriate credit to the original author(s) and the source, provide a link to the Creative Commons license, and indicate if changes were made.

\section{References}

Adhyaru DN, Bhatt NS, Modi HA (2015) Optimization of upstream and downstream process parameters for cellulase-poor-thermosolvent-stable xylanase production and extraction by Aspergillus tubingensis FDHN1. Bioresour Bioprocess 2:3

Ahmed S, Riaz S, Jamil A (2009) Molecular cloning of fungal xylanases: an overview. Appl Microbiol Biotechnol 84(1):19-35

Bagewadi ZK, Mulla SI, Ninnekar HZ (2016) Purification and characterization of endo $\beta$-1,4-D-glucanase from Trichoderma harzianum strain HZN11 and its application in production of bioethanol from sweet sorghum bagasse. 3. Biotech 6:101

Bailey MJ, Biely P, Poutanen K (1992) Interlaboratory testing of methods for assay of xylanase activity. J Biotechnol 23:257-270

Beg QK, Kapoor M, Mahajan L, Hoondal GS (2001) Microbial xylanases and their industrial applications: a review. Appl Microbiol Biotechnol 56:326-338

Driss D, Bhiri F, Siela M, Ghorbel R, Chaabouni SE (2012) Purification and properties of a thermostable xylanase GH 11 from Penicillium occitanis Pol6. Appl Biochem Biotechnol 168(4):851-863

Eveleigh DE, Mandels M, Andreotti R, Roche C (2009) Measurement of saccharifying cellulase. Biotechnol Biofuels 2:21

Ewing B, Hillier L, Wendl M, Green P (1998) Base-calling of automated sequencer traces using phred. I. Accuracy assessment. Genome Res 8(3):175-185

Fang TJ, Liao BC, Lee SC (2010) Enhanced production of xylanase by Aspergillus carneus M34 in solid-state fermentation with agricultural waste using statistical approach. New Biotechnol 27:25-32

Guillen D, Sanchez S, Rodriguez-Sanoja R (2010) Carbohydratebinding domains: multiplicity of biological roles. Appl Microbiol Biotechnol 85(5):1241-1249

Henrissat B, Bairoch A (1996) Updating the sequence-based classification of glycosyl hydrolases. Biochem J 316:695-696

Jørgensen H, Eriksson T, Börjesson J, Tjerneld F, Olsson L (2003) Purification and characterization of five cellulases and one xylanase from Penicillium brasilianum IBT 20888. Enzyme Microb Technol 32:851-861

Juturu V, Wu JC (2012) Microbial xylanases: engineering, production and industrial applications. Biotechnol Adv 30(6):1219-1227
Knob A, Carmona EC (2010) Purification and characterization of two extracellular xylanases from Penicillium sclerotiorum: a novel acidophilic xylanase. Appl Biochem Biotechnol 162(2):429-443

Knob A, Beitel SM, Fortkamp D, Terrasan CR, de Almeida AF (2013) Production, purification, and characterization of a major Penicillium glabrum xylanase using Brewer's spent grain as substrate. Biomed Res Int 2013:728735

Laemmli UK (1970) Cleavage of structural proteins during the assembly of the head of bacteriophage T4. Nature 227(5259):680-685

Liao H, Xu C, Tan S, Wei Z, Ling N, Yu G, Raza W, Zhang R, Shen Q, Xu Y (2012) Production and characterization of acidophilic xylanolytic enzymes from Penicillium oxalicum GZ-2. Bioresour Technol 123:117-124

Liao H, Sun S, Wang P, Bi W, Tan S, Wei Z, Mei X, Liu D, Raza W, Shen $Q$ et al (2014) A new acidophilic endo- $\beta-1,4$-xylanase from Penicillium oxalicum: cloning, purification, and insights into the influence of metal ions on xylanase activity. J Ind Microbiol Biotechnol 41:1071-1083

Liao H, Zheng H, Li S, Wei Z, Mei X, Ma H, Shen Q, Xu Y (2015) Functional diversity and properties of multiple xylanases from Penicillium oxalicum GZ-2. Sci Rep 5:12631

Lin C, Shen Z, Zhu T, Qin W (2015) Newly isolated Penicillium ramulosum $\mathrm{N} 1$ is excellent for producing protease-resistant acidophilic xylanase. J Mol Microbiol Biotechnol 25:320-326

Liu W, Shi P, Chen Q, Yang P, Wang G, Wang Y, Luo H, Yao B (2010) Gene cloning, overexpression and characterization of a xylanase from Penicillium sp. CGMCC 1669. Appl Biochem Biotechnol 162(1):1-12

Maity C, Ghosh K, Halder SK, Jana A, Adak A, Das Mohapatra PK, Pati BR, Mondal KC (2012) Xylanase isozymes from the newly isolated Bacillus sp. CKBx1D and optimization of its deinking potentiality. Appl Biochem Biotechnol 167(5):1208-1219

Miao Y, Li J, Xiao Z, Shen Q, Zhang R (2015) Characterization and identification of the xylanolytic enzymes from Aspergillus fumigatus Z5. BMC Microbiol 15:126

Miller GL (1959) Use of dinitrosalicyclic acid reagent for determination of reducing sugar. Biotechnol Bioeng Symp 5:193-219

Moretti MM, Bocchini-Martins DA, Silva RD, Rodrigues A, Sette LD, Gomes E (2012) Selection of thermophilic and thermotolerant fungi for the production of cellulases and xylanases under solid-state fermentation. Braz J Microbiol 43(3):1062-1071

Mulla SI, Wang H, Sun Q, Hu A, Yu C-P (2016) Characterization of triclosan metabolism in Sphingomonas sp. strain YL-JM2C. Sci Rep 6:21965

Silva LAO, Terrasan CRF, Carmona EC (2015) Purification and characterization of xylanases from Trichoderma inhamatum. Electron J Biotechnol 18:307-313

Tamura K, Stecher G, Peterson D, Filipski A, Kumar S (2013) MEGA6: molecular evolutionary genetics analysis version 6.0. Mol Biol Evol 30(12):2725-2729

Tanaka H, Nakamura T, Hayashi S, Ohta K (2005) Purification and properties of an extracellular endo-1,4-beta-xylanase from Penicillium citrinum and characterization of the encoding gene. J Biosci Bioeng 100(6):623-630

Teshome HR, Charles SW (2014) Sweet sorghum as a bioenergy crop: literature review. Biomass Bioenergy 64:348-355

Wakiyama M, Tanaka H, Yoshihara K, Hayashi S, Ohta K (2008) Purification and properties of family-10 endo-1,4-beta-xylanase from Penicillium citrinum and structural organization of encoding gene. J Biosci Bioeng 105(4):367-374

Zhang J, Siika-Aho M, Puranen T, Tang M, Tenkanen M, Viikari L (2011) Thermostable recombinant xylanases from Nonomuraea flexuosa and Thermoascus aurantiacus show distinct properties in the hydrolysis of xylans and pretreated wheat straw. Biotechnol Biofuels 4:12

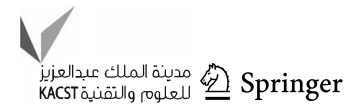

